\title{
The role of personality and love style in marital satisfaction: Does similarity matter?
}

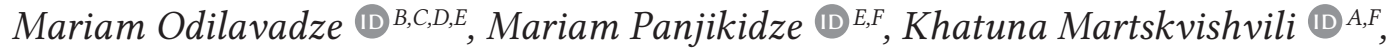 \\ Maia Mestvirishvili (DD ${ }^{D, G}$, Mariam Kvitsiani $\mathbb{D D}^{B, C}$ \\ Ivane Javakhishvili Tbilisi State University, Tbilisi, Georgia
}

BACKGROUND

Scientific study of marital satisfaction attracted widespread attention decades ago. Since then, hundreds of studies have been conducted on determinants of marital satisfaction. The present study attempted to extend previous research on marital life by discussing two important correlates of marital satisfaction: personality traits and love styles. By emphasizing the similarity of personality traits and attitudes toward love in dyads, the study seeks the possible influential constituents for marital outcomes.

\section{PARTICIPANTS AND PROCEDURE}

Eighty-seven $(N=174)$ married heterosexual couples recruited through a convenience sampling procedure participated in the study. They completed the following questionnaires: the HEXACO Personality Inventory, Love Attitudes Scale, and Revised Dyadic Adjustment Scale (RDAS).

\section{RESULTS}

Husbands' honesty/humility level was positively correlated with their own and wives' marital satisfaction. Spouses were similar in some love styles. The discrepancy in their attitudes toward love may have negative as well as positive outcomes, depending on whether we consider husbands' or wives' marital satisfaction. Personality traits and love styles discrepancy scores predicted participants' marital satisfaction.

\section{CONCLUSIONS}

Personality traits and love styles play a significant role in marital satisfaction for both women and men. Marital satisfaction has somewhat different correlates in the case of wives and husbands. Having a different personality or love styles also has different associations with the marital satisfaction of spouses.

KEY WORDS

HEXACO personality traits; love styles; marital satisfaction

CORRESPONDING AUthor - Mariam Odilavadze, Department of Psychology, Ivane Javakhishvili Tbilisi State University,

Ilia Chavchavadze Avenue, Block 3, GE 0179 Tbilisi, Georgia, e-mail: mariami.odilavadze233@pes.tsu.edu.ge

AUthors' Contribution - A: Study design - B: Data collection - C: Statistical analysis - D: Data interpretation .

E: Manuscript preparation · F: Literature search · G: Funds collection

to Cite this ARticle - Odilavadze, M., Panjikidze, M., Martskvishvili, K., Mestvirishvili, M., \& Kvitsiani, M. (2019).

The role of personality and love style in marital satisfaction: Does similarity matter? Current Issues in Personality

Psychology, 7(4), 288-297.

RECEIVED 10.07.2019 • REVIEWED 20.11.2019 ACCEPTED · 21.11.2019 • PUBLISHED 30.12.2019 


\section{BACKGROUND}

Marriage is described as the most important and fundamental human relationship providing the structure for building a family relationship (Larson \& Holman, 1994). Marital satisfaction is an important factor affecting the whole family (Javanmard \& Garegozlo, 2013). While marriage seems to be a desired form of relationship, statistics indicate that marital satisfaction is not easily achieved: Nearly half of first marriages end up in divorce, and the same can be said about cohabiting couples (Bianchi \& Casper, 2000; Bramlett \& Mosher, 2002). This raises the question: What are the key elements of a successful marriage?

For decades, researchers have been trying to identify the factors contributing to marital satisfaction (see Decuyper, De Bolle, \& De Fruyt, 2012). Assortative mating (Buss, 1985; Luo, 2017) assumes that people have the tendency to pair with romantic partners like themselves. Researchers have also tried to detect how the level of partners' similarity in personality traits relates to the quality of the relationship (Lampis, Cataudella, Busonera, \& Carta, 2018; Gray \& Coons, 2017). There are two empirical perspectives regarding the topic. The similarity hypothesis (Byrne, 1971) suggests that when the partners have similar levels for the same traits, attraction and relationship adjustment are the highest. According to the complementarity hypothesis (Winch, Kstanes, \& Kstanes, 1954) "opposites are attracted to each other by the balance principle" (Kristof-Brown \& Jansen, 2007, p. 131), and partners are more satisfied when there is a difference in certain personality variables (Shiota \& Levenson, 2007).

\section{PERSONALITY AND MARITAL SATISFACTION}

Past research revealed the personality as linked to mate selection and related to relationship satisfaction and marital stability (Donnellan, Conger, \& Bryant, 2004). Overall, personality has been a broadly and conspicuously explored predictor for relationship outcomes (Malouff, Thorsteinsson, Schutte, Bhullar, \& Rooke, 2010; Weidmann, Ledermann, \& Grob, 2017).

Studies consistently show that neuroticism is the most problematic characteristic in a relationship context. Research indicates (Barelds, 2005; Karney \& Bradbury, 1995; Javanmard \& Garegozlo, 2013) that neuroticism significantly negatively correlates with marital satisfaction, and a high rate of neuroticism is associated with marital discontent.

In the case of the remaining personality traits (Openness, Conscientiousness, Extraversion, Agreeableness), by contrast, there is no similar consistency. For example, researchers (Karney \& Bradbury, 1995) have not found associations between marital satisfaction and agreeableness, conscientiousness and extra- version; however, in more recent studies, these traits are positively associated with relationship satisfaction (Dyrenforth, Kashy, Donnellan, \& Lucas, 2010; Shahmoradi, Maleki, Maleki, Shahmoradi, \& Entesar Foumany, 2014). Although existing studies give a central role to neuroticism, Claxton and colleagues (2012) show that conscientiousness is most widely associated with marital satisfaction in long-married couples. Finally, openness to experience shows inconsistent results concerning relationship outcomes (Dyrenforth et al., 2010).

Big five personality traits also have interpersonal effects as marital outcomes, namely, relationship quality and stability are also affected by both partners' personality traits (Dyrenforth et al., 2010; Finn, Mitte, \& Neyer, 2013; Malouff et al., 2010). For example, neuroticism, agreeableness, and conscientiousness have intrapersonal as well as interpersonal effects on life or relationship satisfaction (Weidmann, Ledermann, \& Grob, 2016).

Over the last decade a substantial number of studies have focused on understanding what role personality trait similarity/discrepancy plays in partner selection and what their predictive quality is for adult romantic relationships (Lampis et al., 2018). Previous studies tried to examine associations between romantic partners' personality trait similarity and relationship satisfaction and delivered diverse findings (Altmann, Sierau, \& Roth, 2013; Luo, 2009). Some of them showed that partners' personality similarity on a variety of characteristics is related to relationship quality (Gonzaga, Campos, \& Bradbury, 2007; Luo \& Klohnen, 2005; Brauer \& Proyer, 2018). However, other studies have found non-significant or even negative associations between similarity and relationship quality (Proyer, Brauer, Wolf, \& Chick, 2019; Shiota \& Levenson, 2007).

Furler and colleagues (2013) found that partners' similarity on agreeableness had only a small effect on partners' overall life satisfaction. Also, similarity in personality traits is positively associated with females' relationship satisfaction but negatively with males' relationship satisfaction (Gray \& Coons, 2017). In addition, the assumption that the perfect combination of partners' personality contributes to the relationship satisfaction above and beyond the contribution of the personality of both partners was not confirmed (Weidmann et al., 2017).

\section{LOVE AND MARITAL SATISFACTION}

Love is closely associated with marital satisfaction and it is one of the key factors in achieving it (Dion \& Dion, 1991; Contreras, Hendrick, \& Hendrick, 1996).

The classification of love offered by Lee (1973) implies the existence of six love styles, expressing the way people reveal and experience romantic relation- 
ship. Six love styles - Eros, Storge, Agape, Ludus, Pragma, and Mania - have been postulated in the literature as emphasizing different intrinsic attitudes towards love (e.g., Hendrick \& Hendrick, 1986).

Eros (passionate love) emphasizes strong physical attraction, emotional intensity, commitment, and seeing the lover as "the one." Storge (friendship love) incorporates companionship-driven love and commitment. Agape (all-giving, selfless love) is composed of commitment and partner-centeredness, inspired by the belief that his or her duty is to love the partner in exchange for nothing. Ludus (game-playing love) involves a relationship with several partners, accepts deception and manipulation, whereas strong emotional connection, commitment, and jealousy are avoided. Pragma (logical, "shopping list" love) assumes compatibility and determination of future goals, and Mania (possessive, dependent love) includes intense emotional dependency and jealousy (Hendrick \& Hendrick, 1986).

Eros, Agape, and Ludus have been found to be associated with relationship satisfaction (Davis \& Latty-Mann, 1987). Love styles are also associated with some relationship-maintenance behaviors (Hammock \& Richardson, 2011). Ludus is associated with low loyalty, short and unrestricted relationships and having positive feelings about the dissolution of a partnership. Agape and Mania are most evident during the maintenance period of a relationship, which is confirmed by having indicators such as involvement and loyalty. Romantic and altruistic love overall shows positive associations with relationship satisfaction, whereas the association with possessive and ludic love is negative (Rohmann, Führer, \& Bierhoff, 2016; Vedes et al., 2016).

The research findings indicate that among love styles Eros significantly contributes to marital satisfaction (Gana, Saada, \& Untas, 2013). Moreover, couples' love styles affect the marital adjustment (Farah \& Shahram, 2011). There is a relationship between the love styles, love satisfaction, compassionate love, and commitment and adjustment (Neto, 2015). Love style employed by men and women and the rate of infidelity and marital satisfaction correlate significantly (Hosseini, Mazaheri, \& Ahadi, 2015). Women's satisfaction with marital life increases in accordance with husbands' sympathy and love (Cohen, Schulz, Weiss, \& Waldinger, 2012).

\section{PRESENT STUDY}

Although a large volume of research on marital satisfaction relates to personality traits and partners' trait-similarity as well as to the role of attitudes toward love in a marital context, there is a lack of evidence in one of the less studied areas: In particular, there are few studies using the HEXACO per- sonality model of personality traits when assessing the impact of personality traits on marital satisfaction (Sohrabi \& Narimani, 2018), so the role of the honesty/humility trait on marital satisfaction needs farther examination. Furthermore, while individuals report a preference for a partner with a similar love style to their own (Hahn \& Blass, 1997), there is little evidence of whether couples' love style combination exerts an influence on marital satisfaction (Davis \& Latty-Mann, 1987).

The present study aims to investigate the relationships between HEXACO traits, love styles and marital satisfaction. We expected honesty/humility to be positively related to marital satisfaction for both men and women, since previous studies suggested that humility may be important for relationship functioning in couples (e.g. Farrell et al., 2015). Also, we assumed that similarity (discrepancy) in honesty/humility would be positively correlated with both partners' marital satisfaction as being humble is beneficial when one's partner is humble too (Van Tongeren et al., 2019). And finally, we expected couples to have a similar love style, and discrepancy in love styles might be negatively related to their marital satisfaction.

\section{PARTICIPANTS AND PROCEDURE}

\section{PARTICIPANTS}

The sample was composed of $87(N=174)$ heterosexual couples. Married couples (with at least one year of marriage), who volunteered to participate in the study, were recruited (convenience sample). The average age of participants was 32.80 years $(S D=11.40)$, average age for men $34.30(S D=11.90)$ and 31.70 for women $(S D=11.10)$. The average duration of marriage was 9.10 years $(S D=10.60)$. The average number of children was 1.2. As for the educational status, about $6.4 \%$ of participants received secondary education, about $11.6 \%$ vocational education, and $81.6 \%$ of participants reported having higher education.

\section{PROCEDURE}

Couples were contacted and recruited by the research assistant through recruitment advertisements published in the closed groups through the university's internal network. Interested couples, who responded to an advertisement were contacted and they received the information about the aim of the study. Also, they were informed that their participation was confidential. Additionally, detailed oral and written instructions were provided on how to complete the questionnaires. Later, participants received a link to an online questionnaires. Each couple was asked to log in with the same pre-defined specific code, so it would 
be possible for us to identify dyads. Informed consent was obtained from all participants. Also, couples were asked to answer individually, without discussing or comparing their responses with their spouse.

\section{MEASURES}

Personality traits. The HEXACO model of personality was assessed with the Georgian version of HEXACO 60 (Golijashvili, 2016), the 60-item short version of the HEXACO Personality Inventory-Revised (HEXACO PI-R) (Ashton \& Lee, 2009). It includes six 10-item scales: Honesty-Humility $(\alpha=.64)$, Emotionality $(\alpha=.70)$, Extraversion $(\alpha=.74)$, Agreeableness $(\alpha=.67)$, Conscientiousness $(\alpha=.61)$ and Openness to Experience $(\alpha=.77)$. Response options range from 1 (strongly disagree) to 5 (strongly agree).

Love Attitudes Scale. Love styles were assessed with the Georgian version of the Love Attitudes Scale (Odilavadze, 2016). This is a 42-item questionnaire developed by Hendrick and Hendrick (1986). It includes six 7-item scales which measure six love styles: Eros - passionate love $(\alpha=.79)$, Ludus game-playing love $(\alpha=.67)$, Storge - friendship love $(\alpha=.80)$, Pragma - practical love $(\alpha=.78)$, Mania - possessive, dependent love ( $\alpha=.74)$, Agape - altruistic love $(\alpha=.81)$. Research participants were asked to rate the extent to which each item applies to them on a 5-point Likert scale ranging from 1 (strongly disagree) to 5 (strongly agree).

Marital satisfaction was assessed with the Georgian version of the Revised Dyadic Adjustment Scale (RDAS; Udzlauri, 2014). It is a 14-item scale designed to measure relationship satisfaction (Busby, Christensen, Crane, \& Larson, 1995). RDAS ( $\alpha=.79)$ includes 3 subscales: Dyadic Consensus $(\alpha=.79)-$ degree to which respondent agrees with partner; Dyadic Satisfaction $(\alpha=.69)$ - degree to which respondent feels satisfied with partner; Dyadic Cohesion $(\alpha=.76)$ - degree to which research participant and his/her partner participate in activities together. They are asked to rate the extent to which they agree with each item on a 6-point Likert scale ranging from 0 (always disagree) to 5 (always agree).

\section{DATA ANALYSIS}

Following the recommendations of Kenny and colleagues (2006), for assessment of resemblance between distinguishable dyad members, we used two-tailed bivariate correlations accompanied by confidence intervals (CI).

Path analysis was employed to test the ActorPartner Interdependence Model (APIM). Basic APIM Analysis (Kenny, Kashy, \& Cook, 2006) was used to evaluate couples as the highest unit of analysis. It is possible to assess two kinds of effects within APIM: the actor effect and the partner effect. The analysis was conducted in MPLUS 7 (Muthén \& Muthén, 2012).

Figure 1 presents an example of the path diagram of our model. The effects of a husband's HEXACO personality traits and love style on his marital satisfaction are actor effects, and the effects of his personality traits and love style on his wife's marital satisfaction are partner effects. In the same manner actor and partner effects are defined for the wife. Separate
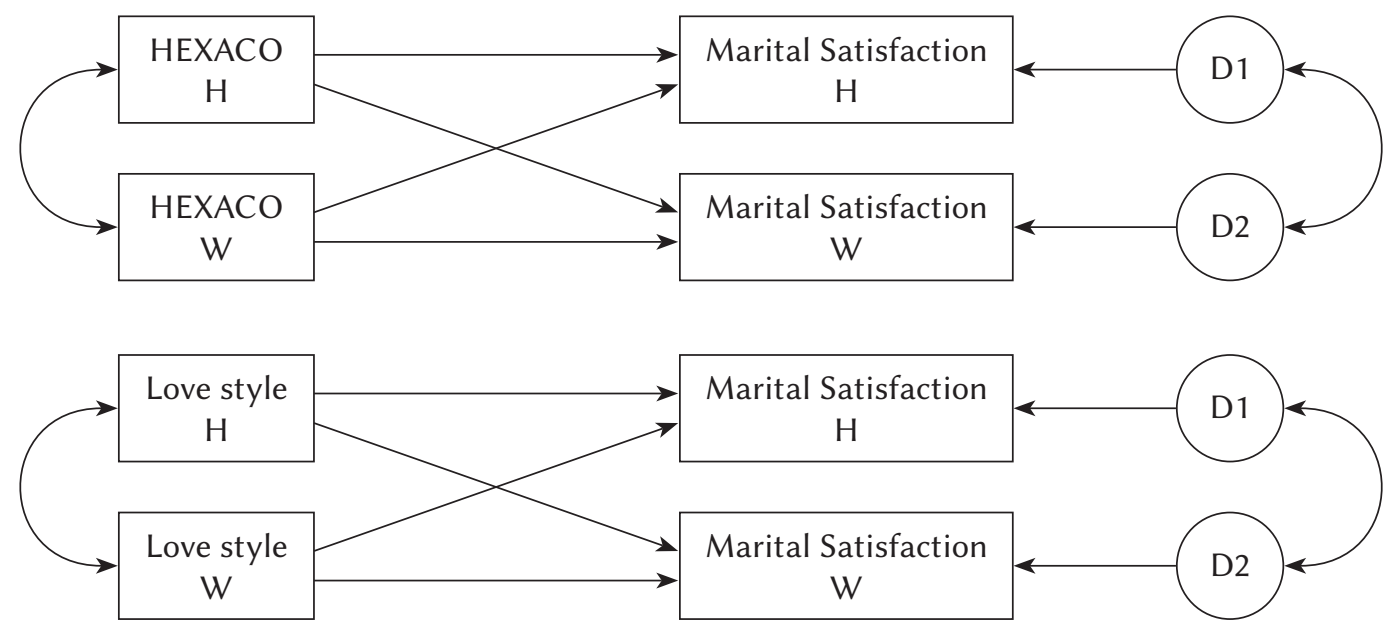

H - husband, W - wife, D - disturbance.

Separate APIMs were computed for each HEXACO trait and each love style. For example, to test honesty/humility trait APIM we put in the model husband and wife scores of honesty/humility as predictor variables and husband and wifes scores of marital satisfaction as outcome variables.

Figure 1. APIM Model. 
APIMs were computed for each HEXACO trait and each love style.

The discrepancy score across measures of personality traits and love styles was calculated by subtracting wives' scores from husbands' scores and multiplying it by itself so that a high score indicated difference and a low score indicated similarity. Using multiple regression analysis, we tested whether personality traits and love style discrepancy scores predicted participants' ratings of marital satisfaction.

\section{RESULTS}

Women $(M=33.96, S D=5.20)$ scored significantly higher on the Emotionality scale, $t(169)=-3.88$, $p<.001 ; 95 \%$ CI $[-5.16 ;-1.67]$ than men $(M=30.58$, $S D=6.20)$, whilst men $(M=27.10, S D=4.90)$ scored significantly higher on the Agape scale, $t(171)=2.46$, $p<.05 ; 95 \%$ CI $[3.27 ; 3.21]$ than women $(M=25.30$, $S D=4.50)$. No other sex differences were identified.
As shown in Table 1, only 4 out of 16 measures of husbands' and wives' scores significantly correlated positively. Of the love styles, the highest spousal similarity occurred in Eros love style $(r=.50, p<.001$; 95\% CI $[.38 ; .65]$ and the lowest one in Agape style $(r=.25, p=.050 ; 95 \%$ CI $[.03 ; .44]$. There was no significant correlation between wives' and husbands' total scores on marital satisfaction measure; however, two subscales - Dyadic Satisfaction $(r=.28, p<.001 ; 95 \%$ CI $[.13 ; .49])$ and Dyadic Cohesion $(r=.26, p=.050$; $95 \%$ CI $[-.10 ; .70])$ - did correlate positively.

APIM analysis showed that the effect of husband's honesty/humility appears to positively influence his own marital satisfaction $(b=.29, p=.045)$. Moreover, husband's honesty/humility affected his partner's marital satisfaction positively $(b=.30, p=.039)$. Two other partner effects were statistically significant and positive: husband's Conscientiousness on his partner's marital satisfaction $(b=.33, p=.027)$ and wife's extraversion on her partner's marital satisfaction $(b=.29, p=.028)$.

Table 1

Two-tailed bivariate correlations between wives' and husbands' scores on measures used in this study $(N=87$ couples $)$

\begin{tabular}{|c|c|c|c|}
\hline & \multirow{2}{*}{$\begin{array}{c}\text { Bivariate } \\
\text { correlations }\end{array}$} & \multicolumn{2}{|c|}{$95 \%$ confidence interval } \\
\hline & & Lower & Upper \\
\hline \multicolumn{4}{|l|}{ HEXACO } \\
\hline Honesty/humility & -.04 & -.22 & .32 \\
\hline Emotionality & -.01 & -.24 & .23 \\
\hline Extraversion & -.04 & -.25 & .14 \\
\hline Agreeableness & .08 & -.11 & .30 \\
\hline Conscientiousness & .02 & -.07 & .35 \\
\hline Openness & .18 & .15 & .53 \\
\hline \multicolumn{4}{|l|}{ Love Style } \\
\hline Eros & $.50^{* *}$ & .38 & .65 \\
\hline Ludus & -.14 & -.27 & .30 \\
\hline Storge & $.34^{* *}$ & .01 & .10 \\
\hline Pragma & .03 & -.04 & .58 \\
\hline Mania & -.10 & -.23 & .55 \\
\hline Agape & $.25^{*}$ & .03 & .44 \\
\hline \multicolumn{4}{|l|}{ Marital Satisfaction } \\
\hline Dyadic Consensus & -.04 & -.16 & .56 \\
\hline Dyadic Satisfaction & $.28^{* *}$ & .13 & .49 \\
\hline Dyadic Cohesion & $.26^{*}$ & -.10 & .70 \\
\hline RDAS & .18 & -.08 & .59 \\
\hline
\end{tabular}

Note. ${ }^{* *} p<.01,{ }^{*} p<.05$. RDAS - total score of marital satisfaction. 
Wife's and husband's Eros love style positively affected their own marital satisfaction $(b=.68, p=.009$ and $b=.58, p=.033$, respectively). The effect of wife's Ludus love style on her marital satisfaction was negative $(b=-.59, p=.022)$, whilst the endorsement of Agape love style had a positive impact on wife's marital satisfaction $(b=.75, p<.001)$.

We tested whether the discrepancy of partners in different traits and love styles had an impact on marital satisfaction. The discrepancy in personality traits of emotionality, conscientiousness, and openness was positively correlated with both husbands' and wives' marital satisfaction (see Table 2); however, honesty/ humility trait discrepancy was positively associated only with wives' marital satisfaction. Regarding the discrepancy of partners' love styles, Ludus and Pragma discrepancy score positively correlated with husbands' marital satisfaction, while Storge style associated negatively. The only love style discrepancy score that was associated with wives' marital satisfaction was Mania.

Multiple regression analysis was used to test whether the personality traits and love styles discrepancy scores predicted participants' ratings of marital satisfaction. It was found that the personality trait discrepancy scores explained $38.5 \%$ of the variance $\left(R^{2}=.38, F(6.80)=3.32, p<.05\right)$ for men and $32.5 \%$ of variance $\left(R^{2}=.32, F(6.80)=6.41\right.$, $p<.01)$ for women. It was found that Honesty/Humility $(\beta=.34, p<.01)$, Extraversion $(\beta=.25, p<.05)$, Agreeableness $(\beta=-.22, p<.05)$ and Conscientiousness $(\beta=.32, p<.05)$ significantly predicted marital satisfaction for women. Also, multiple regression showed that the love style discrepancy scores explained $40.3 \%$ of the marital satisfaction variance $\left(R^{2}=.40, F(6.80)=8.99, p<.01\right)$ for men, where Ludus $(\beta=.38, p<.01)$, Storge $(\beta=-.51, p<.01)$, and Pragma $(\beta=.34, p<.01)$ love styles were significant. For women, $19.1 \%$ of variance of marital satisfaction scores $\left(R^{2}=.19, F(6.80)=3.16, p<.05\right)$ was explained, and only the Mania love style $(\beta=.44, p<.01)$ discrepancy score was significant.

\section{DISCUSSION}

The results revealed associations between personality traits, love styles and marital satisfaction, and the role of personality trait discrepancy and different love style endorsement in couples' marital satisfaction.

As the data show, husbands' honesty/humility level positively affects their own marital satisfaction and it has a positive impact on wives' marital satisfaction too. Wives' honesty/humility was not significantly associated neither with their own or with husbands' marital satisfaction. Hence, the hypothesis of a positive association of honesty/humility with marital satisfaction for men and women was partially supported.
This result fits with existing knowledge that there is a positive and significant correlation between honesty/humility and marital satisfaction (Sohrabi \& Narimani, 2018). The positive pole of the honesty/humility trait - honesty, fairness, modesty, and greed avoidance (Ashton et al., 2004) - is well-suited to partner relationships. Individuals with higher levels of honesty/humility ascribe value to loyalty to their spouses and are psychologically and emotionally involved (Bourdage, Lee, Ashton, \& Perry, 2007).

Further, the discrepancy in personality traits of emotionality, conscientiousness, and openness is positively correlated with both husbands' and wives' marital satisfaction, but honesty/humility trait discrepancy is associated only with wives' marital satisfaction. Thus, the hypothesis that the similarity (discrepancy) in honesty/humility is positively correlated with both partners' marital satisfaction was partially supported. In other words, greater difference across personality traits is associated with greater marital satisfaction, supporting the perspective of the complementarity hypothesis (Winch et al., 1954).

In order to explain why the complementary principle matters only for the female partners' marital satisfaction a little cultural context is required. The expectations for honesty in men in patriarchal societies are lower, whereas women's honesty is au-

Table 2

Correlation between discrepancy scores across measures and marital satisfaction for husbands and wives

\begin{tabular}{ccc}
\hline Discrepancy score & $\begin{array}{c}\text { Husbands' } \\
\text { marital } \\
\text { satisfaction }\end{array}$ & $\begin{array}{c}\text { Wives' } \\
\text { marital } \\
\text { satisfaction }\end{array}$ \\
\hline
\end{tabular}

HEXACO

$\begin{array}{lcc}\text { Honesty/humility } & .01 & .32^{* *} \\ \text { Emotionality } & .25^{*} & .22^{*} \\ \text { Extraversion } & .17 & .21 \\ \text { Agreeableness } & .19 & -.07 \\ \text { Conscientiousness } & .26^{*} & .32^{* *} \\ \text { Openness } & .23^{*} & .31^{* *}\end{array}$

Love Style

\begin{tabular}{lcc} 
Eros & .02 & .01 \\
Ludus & $.39^{* *}$ & -.03 \\
Storge & $-.29^{* *}$ & -.04 \\
Pragma & $.29^{* *}$ & -.01 \\
Mania & -.01 & $.42^{* *}$ \\
Agape & -.05 & -.02 \\
\hline
\end{tabular}

Note. ${ }^{* *} p \leq .01,{ }^{*} p \leq .05$ 
tomatically assumed, so men's honesty is more important.

As for love styles, Eros greatly contributed to marital satisfaction for men as well as for women; however, only the actor effects were detected. This result is consistent with the finding of Contreras and colleagues (1996), suggesting that Eros love style is the strongest consistent predictor of marital satisfaction, for both wives and husbands. Nevertheless, this somehow contradicts the notion that wives' Eros love style has a positive impact on husbands' marital satisfaction, but not the opposite - husband's Eros love style does not affect wives' marital satisfaction (Gana et al., 2013).

As the results show, wife's altruistic love affects positively her own marital satisfaction and no other significant actor or partner effect was detected. Previous research demonstrated that Agape love style is strongly associated with relationship satisfaction (Lin \& Huddleston-Casas, 2005). Also, another study (Gana et al., 2013) showed that only the husband's Agape love style had a positive impact on his own marital satisfaction.

Also, contrary to Gana and colleagues (2013), who observed no actor or partner effects for Ludus love style, in our research ludic love showed a significant actor effect. Game-playing love was negatively correlated with marital satisfaction for wives only. This is in line with the previous findings (Dinani, Zarbakhsh, Samkhaniyan, Hamidi, \& Arkiyan, 2014) that ludic love has predictive value for marital satisfaction, and the association with relationship satisfaction is negative (Rohmann et al., 2016; Vedes et al., 2016). To explain why Ludus love style negatively affected marital satisfaction for wives' only, we rely on the life history theory Figueredo et al. (2006), which states that men and women differ in their psychological systems that outline the different life strategies. Maybe this is not because men and women differ in adopting love styles, but instead, the difference is in their underlying psychological systems that define satisfaction. While the male partner feels more tolerant towards "game-playing" during marriage, the female partner finds it disturbing to have a game-playing attitude in marriage.

Eros, Storge and Agape love style showed low to medium correlations between spouses; as expected, couples have a similar love style. The result represents evidence supporting the notion that couples usually resemble each other in most love styles (Hendrick, Hendrick, \& Adler, 1988; Davis \& Latty-Mann, 1987).

The results showed that love style discrepancy scores correlate significantly with wives' and husbands' marital satisfaction. If the spouses have different attitudes toward a romantic relationship, this distinction is associated differently with marital satisfaction of men and women. Husband's marital satisfaction is correlated with the discrepancy in Lu- dus, Storge and Pragma love styles. More precisely, larger differences in scores on Ludus and Pragma style were correlated with greater relationship satisfaction, and the difference in friendship love style negatively correlated with marital satisfaction. Mania love style was the only style with the discrepancy score positively associated with wives' marital satisfaction. In other words, partners are similar in some love styles. The discrepancy in their attitudes toward love may have negative and positive results as well. So, our hypothesis that if there is a discrepancy in couples' attitudes toward love, this might affect their marital satisfaction negatively, was partially supported.

To sum up, honesty/humility and love styles play a significant role in marital satisfaction for both women and men. Marital satisfaction has different correlates in the case of wives and husbands. Having a different personality or love style has different associations with the marital satisfaction of spouses.

The results of the study might be important for psychotherapists working with couples who are unsatisfied with marriage, struggling or considering divorce. Based on the study findings on how individuals', as well as partners' personality traits and love styles contribute to marital satisfaction, a therapist can give couples an objective perspective on their experiences and provide assets and tools with which couples can boost their marital satisfaction.

\section{LIMITATIONS OF THE STUDY}

We must note some limitations of our study. First, it is a cross-sectional study. A longitudinal study should be encouraged, to determine how couples' love style changes with time and how this change affects marital satisfaction. Second, our sample size was small and using a large sample of married couples is highly recommended. Third, we understand the limitation of self-reported questionnaires, as very limited information can be revealed and more in-depth analysis is not available on data gathered through self-administered questionnaires. Fourth, there are more accurate methods to assess the similarity (discrepancy) between couples such as Response Surface Analysis (Barranti, Carlson, \& Côté, 2017; Schönbrodt, Humberg, \& Nestler, 2018). Fifth, the length of the marriage was not controlled when analyzing the results. This must be taken into consideration for future studies and consequently, comparing spouses with short and long marriage experience is highly recommended. Finally, in the sample, there was overrepresentation of participants with higher education, and this must be taken into account, as a previous study (Alder, 2010) showed that there is a significant association between marital satisfaction and level of education. 


\section{FUNDING}

This work was supported by Shota Rustaveli National Science Foundation of Georgia under grant DP2016_16. Any idea contained in this publication is the property of the authors and may not represent the opinion of the Shota Rustaveli National Science Foundation of Georgia.

\section{References}

Alder, E. S. (2010). Age, education level, and length of courtship in relation to marital satisfaction (Master's thesis). Pacific University, Forest Grove, OR, United States. Retrieved from https://commons. pacificu.edu/spp/145

Altmann, T., Sierau, S., \& Roth, M. (2013). I guess you're just not my type: Personality types and similarity between types as predictors of satisfaction in intimate couples. Journal of Individual Differences, 34, 105-117. https://doi.org/10.1027/1614$0001 / \mathrm{a} 000105$

Ashton, M. C., Lee, K., Perugini, M., Szarota, P., de Vries, R. E., Di Blas, L., Boies, K., \& De Raad, B. (2004). A six-factor structure of personality-descriptive adjectives: Solutions from psycholexical studies in seven languages. Journal of Personality and Social Psychology, 86, 356-366. https://doi. org/10.1037/0022-3514.86.2.356

Ashton, M., \& Lee, K. (2009). The HEXACO-60: a short measure of the major dimensions of personality. Journal of Personality Assessment, 91, 340-345. https://doi.org/10.1080/00223890902935878

Barelds, D. P. H. (2005). Self and partner personality in intimate relationships. European Journal of Personality, 19, 501-518. https://doi.org/10.1002/ per.549

Barranti, M., Carlson, E. N., \& Côté, S. (2017). How to test questions about similarity in personality and social psychology research: Description and empirical demonstration of response surface analysis. Social Psychological and Personality Science, 8, 465-475. https://doi.org/10.1177/1948550617698204

Bianchi, S. M., \& Casper, L. M. (2000). American families. Population Bulletin, 55, 1-46.

Bourdage, J. S., Lee, K., Ashton, M. C., \& Perry, A. (2007). Big Five and HEXACO model personality correlates of sexuality. Personality and Individual Differences, 43, 1506-1516. https://doi. org/10.1016/j.paid.2007.04.008

Bramlett, M. D., \& Mosher, W. D. (2002). Cohabitation, marriage, divorce and re-marriage in the United States. Vital Health Statistics, Series Report 23, No. 2, 1-93.

Brauer, K., \& Proyer, R. T. (2018). To love and laugh: Testing actor-, partner-, and similarity effects of dispositions towards ridicule and being laughed at on relationship satisfaction. Journal of Research in Personality, 76, 165-176. https://doi.org/10.1016/j. jrp.2018.08.008

Busby, D. M., Christensen, C., Crane, D. R., \& Larson, J. H. (1995). A revision of the Dyadic Adjustment Scale for use with distressed and nondistressed couples: Construct hierarchy and multidimensional scales. Journal of Marital and Family Therapy, 21, 289-308. https://doi.org/ 10.1111/j.1752-0606.1995.tb00163.x

Buss, D. (1985). Human mate selection: Opposites are sometimes said to attract, but in fact we are likely to marry someone who is similar to us in almost every variable. American Scientist, 73, 47-51.

Byrne, D. (1971). The attraction paradigm. New York, NY: Academic Press.

Claxton, A., O’Rourke, N., Smith, J. Z., \& DeLongis, A. (2012). Personality traits and marital satisfaction within enduring relationships: an intra-couple discrepancy approach. Journal of Social and Personal Relationships, 29, 375-396. https://doi.org/ 10.1177/0265407511431183

Cohen, S., Schulz, M. S., Weiss, E., \& Waldinger, R. J. (2012). Eye of the beholder: The individual and dyadic contributions of empathic accuracy and perceived empathic effort to relationship satisfaction. Journal of Family Psychology, 26, 236-245. https://doi.org/10.1037/a0027488

Contreras, R., Hendrick, S. S., \& Hendrick, C. (1996). Perspectives on marital love and satisfaction in Mexican American and Anglo-American couples. Journal of Counseling \& Development, 74, 408-415. https://doi.org/10.1002/j.1556-6676.1996.tb01887.x

Davis, K. E., \& Latty-Mann, H. (1987). Love styles and relationship quality: a contribution to validation. Journal of Social and Personal Relationships, 4, 409428. https://doi.org/10.1177/0265407587044002

Decuyper, M., De Bolle, M., \& De Fruyt, F. (2012). Personality similarity, perceptual accuracy, and relationship satisfaction in dating and married couples. Personal Relationships, 19, 128-145. https://doi.org/10.1111/j.1475-6811.2010.01344.x

Dinani, P. T., Zarbakhsh, M., Samkhaniyan, E., Hamidi, M., \& Arkiyan, F. (2014). Study on the relationship between love attitudes and marital satisfaction among married women. European Online Journal of Natural and Social Sciences, 3, 468-474.

Dion, K. K., \& Dion, K. L. (1991). Psychological individualism and romantic love. Journal of Social Behavior \& Personality, 6, 17-33.

Donnellan, M. B., Conger, R. D., \& Bryant, C. M. (2004). The Big Five and enduring marriages. Journal of Research in Personality, 38, 481-504. https:// doi.org/10.1016/j.jrp.2004.01.001

Dyrenforth, P. S., Kashy, D. A., Donnellan, M. B., \& Lucas, R. E. (2010). Predicting relationship and life satisfaction from personality in nationally representative samples from three countries: The rela- 
tive importance of actor, partner, and similarity effects. Journal of Personality and Social Psychology, 99, 690-702. https://doi.org/10.1037/a0020385

Farah, L. K., \& Shahram, V. (2011). The effect of sexual skills training on marital satisfaction. Procedia - Social and Behavioral Sciences, 30, 2581-2585. https://doi.org/10.1016/j.sbspro.2011.10.505

Farrell, J. E., Hook, J. N., Ramos, M., Davis, D. E., Van Tongeren, D. R., \& Ruiz, J. M. (2015). Humility and relationship outcomes in couples: The mediating role of commitment. Couple and Family Psychology: Research and Practice, 4, 14-26. https://doi. org/10.1037/cfp0000033

Figueredo, A. J., Vásquez, G., Brumbach, B. H., Schneider, S. M. R., Sefcek, J. A., Tal, I. R., Hill, D., Wenner, C. J., \& Jacobs, W. J. (2006). Consilience and life history theory: From genes to brain to reproductive strategy. Developmental Review, 26, 243-275. https://doi.org/10.1016/j.dr.2006.02.002

Finn, C., Mitte, K., \& Neyer, F. J. (2013). The relationship-specific interpretation bias mediates the link between neuroticism and satisfaction in couples: The relationship-specific interpretation bias. European Journal of Personality, 27, 200-212. https://doi. org/10.1002/per.1862

Furler, K., Gomez, V., \& Grob, A. (2013). Personality similarity and life satisfaction in couples. Journal of Research in Personality, 47, 369-375. https://doi. org/10.1016/j.jrp.2013.03.002

Gana, K., Saada, Y., \& Untas, A. (2013). Effects of love styles on marital satisfaction in heterosexual couples: a dyadic approach. Marriage \& Family Review, 49, 754-772. https://doi.org/10.1080/01494929.2013. 834025

Golijashvili, N. (2016). Psychometric properties of the Georgian version of HEXACO Personality Inventory (Unpublished master's thesis). Ivane Javakhishvili Tbilisi State University, Tbilisi, Georgia.

Gonzaga, G. C., Campos, B., \& Bradbury, T. (2007). Similarity, convergence, and relationship satisfaction in dating and married couples. Journal of Personality and Social Psychology, 93, 34-48. https:// doi.org/10.1037/0022-3514.93.1.34

Gray, J. S., \& Coons, J. V. (2017). Trait and goal similarity and discrepancy in romantic couples. Personality and Individual Differences, 107, 1-5. https://doi. org/10.1016/j.paid.2016.11.024

Hahn, J., \& Blass, T. (1997). Dating partner preferences: a function of similarity of love styles. Journal of Social Behavior and Personality, 12, 595-610.

Hammock, G., \& Richardson, D. S. (2011). Love attitudes and relationship experience. The Journal of Social Psychology, 151, 608-624. https://doi.org/10. 1080/00224545.2010.522618

Hendrick, C., \& Hendrick, S. (1986). A theory and method of love. Journal of Personality and Social Psychology, 50, 392-402. https://doi.org/10.1037/ 0022-3514.50.2.392
Hendrick, S. S., Hendrick, C., \& Adler, N. L. (1988). Romantic relationships: Love, satisfaction, and staying together. Journal of Personality and Social Psychology, 54, 980-988. https://doi.org/10.1037/ 0022-3514.54.6.980

Hosseini, S. S., Mazaheri, M. A., \& Ahadi, H. (2015). Logistic analysis for predicting marital infidelity based on love styles. International Journal of $R e^{-}$ view in Life Sciences, 5, 1029-1034.

Javanmard, G. H., \& Garegozlo, R. M. (2013). The study of relationship between marital satisfaction and personality characteristics in Iranian families. Procedia - Social and Behavioral Sciences, 84, 396399. https://doi.org/10.1016/j.sbspro.2013.06.573

Karney, B. R., \& Bradbury, T. N. (1995). The longitudinal course of marital quality and stability: a review of theory, methods, and research. Psychological Bulletin, 118, 3-34. https://doi.org/10.1037/0033-2909.118.1.3

Kenny, D. A., Kashy, D. A., \& Cook, W. L. (2006). Dyadic data analysis. New York: Guilford Press.

Kristof-Brown, A. L., \& Jansen, K. J. (2007). Issues of person-organization fit. In C. Ostroff \& T. A. Judge (Eds.), Perspectives on organizational fit (pp. 123153). New York: Lawrence Erlbaum Associates.

Lampis, J., Cataudella, S., Busonera, A., \& Carta, S. (2018). Personality similarity and romantic relationship adjustment during the couple life cycle. The Family Journal, 26, 31-39. https://doi.org/ $10.1177 / 1066480717741689$

Larson, J. H., \& Holman, T. B. (1994). Premarital predictors of marital quality and stability. Family $R e^{-}$ lations, 43, 228-237. https://doi.org/10.2307/585327

Lee, J. A. (1973). Colours of love: an exploration of the ways of loving. Toronto: New Press.

Lin, L.W., \& Huddleston-Casas, C. A. (2005). Agape love in couple relationships. Marriage \& Family Review, 37, 29-48. https://doi.org/10.1300/J002v37n04_03

Luo, S. (2009). Partner selection and relationship satisfaction in early dating couples: The role of couple similarity. Personality and Individual Differences, 47, 133-138. https://doi.org/10.1016/j.paid.2009.02.012

Luo, S. (2017). Assortative mating and couple similarity: Patterns, mechanisms, and consequences. Social and Personality Psychology Compass, 11, e12337. https://doi.org/10.1111/spc3.12337

Luo, S., \& Klohnen, E. C. (2005). Assortative mating and marital quality in newlyweds: a couple-centered approach. Journal of Personality and Social Psychology, 88, 304-326. https://doi.org/10.1037/ 0022-3514.88.2.304

Malouff, J. M., Thorsteinsson, E. B., Schutte, N. S., Bhullar, N., \& Rooke, S. E. (2010). The Five-Factor Model of personality and relationship satisfaction of intimate partners: a meta-analysis. Journal of Research in Personality, 44, 124-127. https://doi. org/10.1016/j.jrp.2009.09.004

Muthén, L. K., \& Muthén, B. O. (2012). Mplus. Los Angeles, CA: Muthén and Muthén. 
Neto, F. (2015). Revisiting correlates of sociosexuality for men and women: The role of love relationships and psychological maladjustment. Personality and Individual Differences, 83, 106-110. https://doi. org/10.1016/j.paid.2015.03.033

Odilavadze, M. (2016). The dark side of love: Relationship between aversive personality traits and marital satisfaction (Unpublished master's thesis). Ivane Javakhishvili Tbilisi State University, Tbilisi, Georgia.

Proyer, R. T., Brauer, K., Wolf, A., \& Chick, G. (2019). Adult playfulness and relationship satisfaction: an APIM analysis of romantic couples. Journal of Research in Personality, 79, 40-48. https://doi. org/10.1016/j.jrp.2019.02.001

Rohmann, E., Führer, A., \& Bierhoff, H.W. (2016). Relationship satisfaction across European cultures: The role of love styles. Cross-Cultural Research, 50, 178211. https://doi.org/10.1177/1069397116630950

Schönbrodt, F. D., Humberg, S., \& Nestler, S. (2018). Testing similarity effects with dyadic response surface analysis: Dyadic response surface analysis. European Journal of Personality, 32, 627-641. https://doi.org/10.1002/per.2169

Shahmoradi, G., Maleki, E., Maleki, T., Shahmoradi, Z., \& Entesar Foumany, G. H. (2014). Relationship between marital satisfaction and personality characteristics on the basis of Myers-Briggs Inventory and Big Five Questionnaire. Journal of Education and Management Studies, 4, 787-790.

Shiota, M. N., \& Levenson, R. W. (2007). Birds of a feather don't always fly farthest: Similarity in Big Five personality predicts more negative marital satisfaction trajectories in long-term marriages. Psychology and Aging, 22, 666-675. https://doi. org/10.1037/0882-7974.22.4.666

Sohrabi, Z., \& Narimani, M. (2018). The roles of HEXACO personality dimensions and affects control in prediction of marital satisfaction. Journal of Fundamentals of Mental Health, 20, 219-227.

Udzlauri, N. (2014). Emotional intelligence as a predictor of marital satisfaction (Unpublished master's thesis). Ivane Javakhishvili Tbilisi State University, Tbilisi, Georgia.

Van Tongeren, D. R., Hook, J. N., Ramos, M. J., Edwards, M., Worthington, E. L., Davis, D. E., ... OsaeLarbi, J. A. (2019). The complementarity of humility hypothesis: Individual, relational, and physiological effects of mutually humble partners. The Journal of Positive Psychology, 14, 178-187. https://doi. org/10.1080/17439760.2017.1388433

Vedes, A., Hilpert, P., Nussbeck, F. W., Randall, A. K., Bodenmann, G., \& Lind, W. R. (2016). Love styles, coping, and relationship satisfaction: a dyadic approach. Personal Relationships, 23, 84-97. https:// doi.org/10.1111/pere.12112

Weidmann, R., Ledermann, T., \& Grob, A. (2016). The interdependence of personality and satisfaction in couples: a review. European Psychologist, 21, 284295. https://doi.org/10.1027/1016-9040/a000261

Weidmann, R., Ledermann, T., \& Grob, A. (2017). Big Five traits and relationship satisfaction: The mediating role of self-esteem. Journal of Research in Personality, 69, 102-109. https://doi.org/10.1016/j. jrp.2016.06.001

Winch, R. F., Ktsanes, T., \& Ktsanes, V. (1954). The theory of complementary needs in mate-selection: an analytic and descriptive study. American Sociological Review, 19, 241-249. https://doi.org/10.2307/2087753 